\title{
Ecobiology of coal mines and spoils
}

\author{
Anjali Sharma \\ Department of Botany, University of Jammu, Jammu-180006 (J\&K), India \\ Geeta Sumbali * \\ Department of Botany, University of Jammu, Jammu-180006 (J\&K), India \\ *Corresponding author. E-mail: geetasumbalippl@yahoo.co.in
}

\section{Article Info \\ https://doi.org/ \\ 10.31018/jans.v11i3.2130 \\ Received: June 18, 2019 \\ Revised: July 22, 2019 \\ Accepted: August 21, 2019}

\section{How to Cite}

Sharma, A. and Sumbali, G. (2019). Ecobiology of coal mines and spoils. Journal of Applied and Natural Science, 11(3): 624- $631 \mathrm{https}: / /$ doi.org/ 10.31018/jans.v11i3.2130 etc. that may cause skin, respiratory tract and other health problems. This article light on the impact of coal mining on the surrounding ecosystem, degradation of coal by the microbial inhabitants and their effects on the health of miners.

Keywords: Coal mines, Coal spoils, Microflora, Ecobiology, Microbial degradation, Miners health

\section{INTRODUCTION}

Coal is recognized as an important nonrenewable source of energy widely used in metallurgical industries, thermal power plants and other industries (Barooah and Baruah, 1996). The composition of coal is very complex, consisting mainly of carbon (between $60 \%$ and $95 \%$ ) and few other elements like hydrogen, oxygen and sulphur. Its usefulness in different industries is mainly dependent on its volatile matter, combustible and non-combustible constituents. In fact, coal is the most important fossil fuel and a basic source of energy for industrial development (Aseefa et al., 2013). Throughout the world, coal deposits are larger than those of the crude oil, which is another source of energy. Therefore, coal acts as a raw material source for future fuel generation.

The formation of coal takes millions of years, which starts with accumulation or rearrangement of organic and inorganic chemical constituents in a low oxygen environment. The organic matter accumulates and forms a bed of peat, which gets buried by other sediments and under heat and pressure begins to transform into low grade coal, known as lignite. Further, more heat and pressure metamorphoses the lignite into bituminous coal and then into anthracite, which is hard shiny, compact and crystalline form of coal (Taylor et al., 2009). This whole process of coal formation including metamorphoses of one form of coal into another involves coalification, that is, the degree of change undergone by coal as it matures from peat to anthracite. Coalification has an important bearing on the physical and chemical properties of the coal and is referred to as the 'rank' of the coal. The quality of each coal deposit is determined by the type of vegetation from which the coal has originated, depth of burial, length of time involved in coal formation and few other factors like pressure, humidity, lack of air, microbiological reactions, physical and chemical reactions at those depths (Taylor et al., 2009).

According to World Coal Association (WCA), coal reserves are available in almost every country of the world with recoverable reserves in around 70 countries. It has been estimated that there are over 861 billion tonnes of proven coal reserves world-wide and the biggest reserves are in U.S.A, Russia, China and India. In India, there are 44 major coalfields and the total estimated reserves of all types of coal are 315.149 billion tonnes, extending upto depths of 1,200 meters (US Energy Information Administration, 2017). These deposits are mainly distributed in the states of Bihar and Telangana (Chikkatur et al., 2009).

Coal mining has multi-dimensional impact on the biological species both directly and indirectly. The present article is an attempt to focus on the ecobiology of coal mines and spoils.

Physico-chemical properties of coal mines and spoils: Coal is basically classified into three major types namely anthracite, bituminous and lignite. Anthracite is considered to be the oldest coal from 
geological perspective. It is a hard coal composed mainly of carbon with little moisture and volatile content. On the other hand, lignite is considered to be the youngest coal from geological perspective, which is soft coal, composed of volatile matter and moisture content. Much information is available about the physico-chemical properties of coal. For example, physico-chemical properties and microflora of lignite coal from Mirash mine, near Kastriot, Kosovo have been studied by Plakolli et al (2010). They analysed these samples for ash, $\mathrm{C}, \mathrm{O}, \mathrm{H}, \mathrm{N}, \mathrm{S}$, carbonates and silicates and found that the values of $\mathrm{C}, \mathrm{H}, \mathrm{N}$ and $\mathrm{O}$ were approximately similar in the coal and the bacterial biomass. The physico-chemical characterization of Nigerian coal samples have been determined and found to contain major elements like $\mathrm{Ca}, \mathrm{Fe}$ and $\mathrm{S}$ and some minor elements like $\mathrm{K}, \mathrm{Zn}, \mathrm{Ni}$, Sc, $\mathrm{Ti}$ and $\mathrm{Zr}$ (Adekola et al., 2012). Similarly, Nyakuma (2015) studied physico-chemical properties of three low rank Nigerian coals and determined the elemental composition, proximate analysis, mineral matter and calorific values of the coal. From some Indian coal samples, various physical characteristics like $\mathrm{pH}$ and electrical conductivity and some chemical properties like macroelements viz., nitrogen $(\mathrm{N})$, carbon $(\mathrm{C})$, phosphorus $(P)$, potassium $(K)$, sulphur $(S)$ and some microelements viz., zinc (Zn), copper (Cu) manganese $(\mathrm{Mn})$ and iron $(\mathrm{Fe})$ have also been investigated (Sharma, 2016).

During the process of coal mining, the overlying soil and the fragmented rocks that are removed are usually heaped in the form of overburden dumps. These dumps are usually nutrient poor, loosely adhered particles, which contain high concentration of heavy metals. These overburden dumps create mine spoils when deposited in an un-mined area, affecting landscape and cause environmental pollution (Makdoh and Kayang, 2015). The physico chemical properties of overburden dump materials are site specific and differ from one dump to another dump due to different geological deposit of rocks (Lovesan et al., 1998). Ghose (2001) analysed soil dumps around Raj Mahal coalfield areas of Eastern Coalfield Ltd. and found them to change greatly with age, which ultimately became biologically sterile.

In India, studies have been conducted on the physico-chemical characteristics of overburden dump soil in selected coal mining areas of Jharia, Jharkhand (Rai et al., 2011), Sundargarh, Odisha (Maharana and Patel, 2013), Chirimiri, Chattisgarh (Nigam et al., 2015), Khliehriat, East Jantia Hills district, Megahalaya (Makdoh and Kayang, 2015) and Raniganj, West Bengal (Kar and Palit, 2017). These investigations revealed that the overburden spoils were poor in nutrient content but rich in heavy metals. Ralte (2017) studied the impact of coal mining on soil physico-chemical properties of Nokrek Biosphere Reserve, Meghalaya and found that physico-chemical properties of mine spoils were different from those of the core zone of the biosphere reserve.

Microbial inhabitants of coal mines: The first pure culture of a microbe was that of bacteria, which was found to be growing on brown coal samples (Galle, 1910). Later, more bacteria were shown to be associated with coal by Schroeder (1914) and Lipman (1937). Some microbiologists, geochemists and fuel scientists consider that micro-organisms might be able to metabolize the physico-chemical structure of coal (Hofrichter et al., 1997).

Fungal species inhabiting various types of coal was first given by Fischer and Fuchs (1927). They surprisingly observed white and green mycelial growth on untreated moist coal, which led to the discovery of various filamentous fungi. Later, Lieske and Hofmann (1928) carried out detailed investigations on the micro-flora of coal deposits and a large number of microorganisms were detected from the mining areas. From India, some mycologists have surveyed fungal flora of coal mines. Prasanth et al. (2011) investigated airborne mycoflora near Neyveli lignite mine in Tamil Nadu and recovered predominantly the mitosporic fungi. Tulsiyan et al. (2017) studied fungal diversity of coal mines near Hazaribagh, Jharkhand and recovered 11 fungal species from Class Ascomycetes and Zygomycetes whose optimal growth temperature was $45^{\circ} \mathrm{C}$ or above. Similarly, from J\&K State, Sharma and Sumbali (2017) recovered 33 fungal species belonging to 19 genera from the lignite and anthracite coal mines of Jammu province. They observed lignite type of coal to favour the growth of 30 fungal species, whereas 28 fungal species were recovered from anthracite coal. Of these, Aspergillus accounted for $27 \%$ of the total mycodiversity in both types of coal, followed in decreasing order by Curvularia and Penicillium species (Sharma, 2016).

Microbial degradation of coal: The idea that microorganisms might be able to degrade coal is not new. In the early $20^{\text {th }}$ century, bacteria were reported to act as biocatalysts in the oxidation of coal (Potter, 1908). It has been observed that there is a close connection between microbial activity and coalification as in this process, a number of bacteria and fungi are known to degrade the organic matter and cellulose content by their enzymatic action (Laborda et al., 1997). However, some microbiologists, geochemists and scientists are of the opinion that most of the microorganisms may not be able to modify the chemical structure of coal because they usually prefer simple sugars and organic acids for their activity and avoid the use of complex materials, such as coal (Fakoussa and Hofrichter, 1999). Secondly, less is known to the geochemists about the physico-chemical pro- 
cesses and extreme conditions involved in the genesis of coal, that is, coalification. By studying this process, an idea has emerged that coal might be acted upon by microbes or utilized as growth substrate as it contains $60-95 \%$ of carbon. In fact, coal and different types of micro-organisms have co-existed since the deposition of coal millions of years ago and they have survived in a dormant state, which slowed down their metabolism in order to survive in the unfavourable conditions (Fakoussa and Frost, 1999).

Certain bacterial strains are known to grow on coal by utilizing hard coal as the sole source of carbon. For example, Pseudomonas fluorescens has been used for bioconversion of coal, which could alter several coal characteristics like colour, wettability and extractability (Fakoussa, 1981). Assumptions have been made that secreted enzymes convert the coal substance to more hydrophilic status, that is, it becomes more water soluble and is then taken up by the bacterium (Fakoussa, 1981). Few investigations have also been carried to find out whether yeasts and filamentous fungi could utilize the coal as a sole source of carbon and energy (Fakoussa and Hofrichter, 1999). Interestingly, they found that when the fungal spores germinated, there was no affinity to the coal, but in mature stage many coal particles adhered to the fungal cell wall and the older hyphae became completely coated with the coal layer. Cohen and Gabriele (1982) found that the two white rot fungi, Trametes versicolor and Poria monticola were able to convert leonardite, a low rank coal deposit in North Dakota. Few more researchers have also shown that the fungi and actinomycetes are able to solubilise small amount of $3.2 \mathrm{~N}$ nitric acid oxidized coals in liquid culture (Quigley et al., 1988). Later, Stewart et al. (1990) also investigated colonization of pretreated bituminous coal by a number of filamentous fungi and found Penicillium and Cunninghamella species to be the most active. By using SEM, they observed extensive surface colonization of coal, which included conidia formation and a tight attachment of fungal hyphae to the coal particles. Further, they found that only the pretreated coal samples, which had previously been exposed to $150^{\circ} \mathrm{C}$ for 7 days, showed luxuriant growth of molds, whereas the untreated particles showed little colonization. According to Machnikowska et al. (2002), microbial degradation of coal has been considered as an economic and effective way of transforming macromolecules into simpler, low molecular weight products. Rajak et al. (2014) carried an investigation on the bio-desulphurization of high sulphur coal by using the bacterium, Thiobacillus ferrooxidans and studied different parameters such as variation of $\mathrm{pH}$, reduction of sulphur, ash and nitrogen.

Most of the earlier studies have demonstrated that bacteria and fungi are able to metabolize the low rank coal but less is known about the transformation of hard coal by microorganisms. Osipowicz et al. (1994) found that the white-rot fungus, Piptoporus betulinus and two bacterial strains showed bio-transformation of Polnish hard coal. Monistrol and Laborda (1994) demonstrated liquefaction of Spanish hard coal by forming a tar-like substance using a newly isolated mold. Later on, Hofrichter et al. (1997) screened different fungal strains for their ability to metabolize German hard coal. It was realised that both non-enzymatic and enzymatic mechanisms may be involved in coal degradation/ solubilisation by the same microorganism (Holker et al., 2002; Yuan et al., 2006). Biological desulphurisation of coal was carried out from North Eastern Coalfields of Assam, India by using Aspergillus species isolated from coal itself and as high as $70-80 \%$ of total sulphur removal was achieved (Acharya et al., 2005). Later, Silva-Stenico et al. (2007) reported increase in coal solubilisation efficiency of Trichoderma atroviride ES11 by the addition of nitrogen source such as ammonium sulphate to the medium. Biodepolymerization of low rank Indian coals by using Pleurotus djamor, $P$. citrinopileatus and Aspergillus species were studied and the findings showed that as compared to sub-bituminous and bituminous coal, lignite coal has higher rate of solubilization (Selvi et al., 2009). Similarily, bio-solubilisation of lignite (a low-rank coal) into humic acid was investigated by using fungal organisms and it was found that the microbial dead cells and their metabolites present on the surface of lignite particles reduce the rate of lignite solubilisation (Tripathi et al., 2009). In North China, a fungus, Hypocrea lixii strain TZ1 isolated from coal mine soil at the Fushunxi Colliery, Liaoning Province, has been used for the bioconversion of Chinese lignite (Tao et al., 2010). It is speculated that strain TZ1 produces extracellular enzymes such as polyphenol oxidase, which can utilize amide $\left(-\mathrm{CONH}_{2}\right)$, carboxyl $(-\mathrm{COOH})$ and carboxylate (-COO') group (Holker et al., 2002).

Investigations have also been carried out to study the effect of some filamentous fungi on bioliquefaction of low rank Indian coals, its chemical composition, surface characteristics of the products and the microbial mechanism of coal conversion. Among the fungal strains used, mixed cultures of Aspergillus niger and some Penicillium species caused significant removal of ash and minerals (Balachandran and Elcey, 2010). It has been reported that extracellular enzymes produced by Aspergillus niger, such as laccase, lignin peroxidase and manganese peroxidase play a role in the solubilisation of bituminous coal (Balachandran and Elcey, 2010). Studies have also been done on the bio-demineralization of Indian bituminous coal by Aspergillus niger and characterization of its products. In this process, bio-demineralization sig- 
nificantly reduced the ash content in the coal and the leaching process removed minerals like silicates and pyrites, whereas aluminates were decreased considerably (Balachandran, 2013).

Although some fungi can specifically grow on untreated coals, several research studies have shown that the brown rot fungi in comparison to white rot fungi are weakly active or inactive to solubilise lignite under the same test conditions (Catcheside and Mallett,1991). It has been demonstrated that some filamentous fungi and streptomycetes have the ability to attack low rank coal (leonardite) and modify the physico-chemical structure of coal (Faison, 1991; Fakoussa, 1992; Crawford, 1993). Hofrichter et al. (1997) also demonstrated modification of hard coal by fungi. They screened more than 750 fungal strains for their ability to attack German hard coal and of these; selected six strains could modify the physico-chemical properties of hard coal pieces placed on the overgrown surface of petri-dishes. The fungal strains used for this screening programme were isolated from soil, coal and also included some wood and litter decaying Basidiomycetes. Following this, intensive research was conducted by various other research groups also with an aim of establishing better understanding of coal bioconversion and the production of value added products (Polman et al., 1994; Fakoussa and Frost, 1999; Fakoussa and Hofrichter, 1999; Gotz and Fakoussa, 1999; Machnikowska et al., 2002; Igbinigie et al., 2008; Jiang et al., 2013). Recently, Sharma (2016) observed that the fungal isolates recovered from some Indian coal mines possessed the ability to utilize coal as the sole source of carbon.

Effect of coal microflora on the health of miners: The health of coal miners is always at risk as bioaerosols are ubiquitously present in the coal mines. Bioaerosols may include allergens, pathogenic or non pathogenic bacteria, fungi, viruses and their toxins. Transmission of bioaerosols can occur by the airborne droplets or dust through the skin, respiratory tract and mucous membrane (Rdzanek et al., 2015). Working conditions inside the coal mines are hard due to the depths of the mines, which can be upto thousands of metres, high temperature reaching over $30^{\circ} \mathrm{C}$ and relative humidity ranging between $70-100 \%$ (Drenda, 2012). These prevailing conditions and additionally the presence of organic substances create a congenial environment for microfungal organisms, which can be found on any organic material used in the mining activities especially on timber, organic waste, insulators, machinery tyres or other rubber material surfaces (Piontek and Bednar, 2010). The coal miners while working in the mines, go down and take spores of various microbes into the depths of mine. Some of the airborne microfungi like Aspergillus, Penicillium,
Cladosporium and Stachybotrys species, which usually occur in the mine excavations and galleries can cause allergies and fungal infections in some of the exposed workers (Gamboa et al., 1996; Obtulowikz, 2006; Cabral, 2010). Spores of Aspergillus fumigatus are known agents of cystic fibrosis and allergic bronchopulmonary aspergillosis (Frisvad et al., 2004). In addition, these spores also pose a serious risk for miners as they are inhaled along with the coal dust and cause occupational diseases, such as pneumoconiosis, silicosis and emphysema (Yoltas et al., 2015). Another species, $A$. flavus is also known to be allergenic and causal agent of aspergillosis. Both these fungal species are even known producers of some mycotoxins and other secondary metabolites, which may cause disorders like irritation of the mucous membrane, nausea, immune system deficiency, cancer and acute or chronic damage to the liver and central nervous system (Dutkiewicz, 1997).

Since coal is being used in some of the electric plants even today, coal miners continue to suffer from lung diseases due to coal mine dust. After the passage of Federal Coal Mine Health and Safety Act in 1969 (FCMHSA, 1969), the exposure to coal dust was limited and a decline in the prevalence of pneumoconiosis among coal workers of USA was observed between 1970 and 2000 (Cohen et al., 2016). However, since then, pneumoconiosis among miners has increased significantly and incidence of several forms, such as, massive fibrosis, silicosis and rapidly progressive pneumoconiosis have increased due to modernization of the mining technology, which generates clouds of respirable dust particles containing toxic silica (quartz), silicate particles and the less toxic coal (carbon) particles (Pollock et al., 2010; Perret et al., 2017). Recently, a study demonstrated that the silica/ silicate particles from coal mine dust get accumulated inside the alveolar macrophages and cause a disease called as coal mine dust desqamative chronic interstitial pneumonia, which is a precursor of both coal dust related diffuse fibrosis and emphysema (Jelic et al., 2017).

Since 1990's, some of the developed countries have even implemented the occupational safety and health management system (Tian, 2012; Ma and Dai, 2017; Nie et al., 2018; Zhou et al., 2018). Recently, software system has also been developed for coal mine occupational safety and health management in order to enhance the occupational safety, health management and risk control standards (Cao et al., 2013; Zhou et al., 2018).

Coal mining and its impact on ecosystem: Coal mining activities cause changes in the landscape and degradation of stable ecosystems. Increasing demand for coal is known to destabilize the ecosystem around the mining area, which is contrary to the objectives of sustainable development (Kar 
and Palit, 2017). During the process of mining, variety of materials are washed away as discharge into the waterways, which flows downstream and can contaminate water bodies with various metals (Ali et al., 2017, 2018). These heavy metals discharged from coal mines may be consumed by some aquatic organisms, whereas the low soluble trace metals easily get adsorbed in sediments (Mishra and Shukla, 2016). This continuous process leads to high accumulation of contaminants in the body of living organisms (Alvarez et al., 2011). However, those trace metals, which are not permanently bonded to the sediment can be easily released in the water under different conditions (Wang et al., 2016). Some of the trace metals that are not essential for the biological functions can be toxic at very low concentrations (Pagenkopf, 1983). Such trace metals may accumulate in the body of various organisms including humans (Allinson et al., 2015).

Certain plant and animal species have their own system to maintain the intake of contaminants and capability to accumulate them, irrespective of the available trace metals in the aquatic system (Johnstone et al., 2016). The inhabitants of the coal mining surrounding areas have their characteristic affinity towards the available trace metals. In the presence of certain trace metals, the uptake of other trace metals by inhabitants get reduced and photosynthesis in plants also get affected (Volland et al., 2014). Coal mining also has an impact on the miners and other people residing in and around the mining area.Therefore, in view of the mining activities, concern regarding the local habitats and ecosystem is very important. In this direction, angle of slope of overburden dumps, safe disposal drains and other safe techniques are necessary to reduce the environmental impact (Goswami, 2015).

In addition, burning of coal releases harmful gases, such as, carbon dioxide, nitrogen oxide and sulphur dioxide whose emission has been correlated with many health problems and different cancers of skin, brain, heart, lungs and blood (Badman and Jaffe, 1996, Cornell, 2016). High exposure to sulphur dioxide also leads to suffocation, coughing, wheezing and reduction in lung functioning by affecting mucous and cellular mucins (Kelsall et al., 1997). Sulphur dioxide is also known to damage plants by causing leaf injury and affecting plant growth, thus reducing the diversity of plant species (Barretti and Benedict,1970; Winner et al., 1985). It has been reported that there is a substantial increase in eye and throat irritation, respiratory problems, anxiety related to the smoke and ash and other problems like headaches, nausea, and blurred vision during the periods of fire (Brook, 2014). Coal mine fires also release partially oxidised by-products such as benzene, toulene and xylene (Engle et al., 2013).
Mining activities may even result in soil erosion, destruction of vegetation and thus alteration of associated microbial communities (Goswami, 2015).

Further, the soot and sublimates associated with coal mine fires show the presence of some harmful trace elements such as mercury, arsenic and selenium (Silva et al., 2012; Tulsiyan et al., 2017). Recently, a study has been conducted to assess the impact of coal mining on the aquatic environment using macroinvertebrates and chlorophyll as indicators of industrial pollution. This comparative study showed that in the upstream and downstream locations of two coal mines, invertebrates and chlorophyll do not behave identically to the contaminants in the environment for their survival (Ali et al., 2018). Researchers have examined that, on an average, streams affected by coal mining were $32 \%$ lower in taxonomic richness and $53 \%$ lower in total abundance than unmined streams (Giam et al., 2018).

\section{Conclusion}

The microbial inhabitants of coal mines and their ability to attack the physico-chemical properties of coal is an interesting area of research, which is worth pursuing. Bioconversion of coal that is, biodemineralization, bio-depolymerization, desulphurization, etc., by fungi, actinomycetes and bacteria is of great industrial application. Infact, mining is expected to affect the environment and ecology of a region and the greatest impact is the deterioration of soil quality. The process of bioconversion is also applicable for the management and reclamation of topsoil of coal mining areas. Additionally, microbial flora of coal mines have a major impact on the health of miners. Therefore, indepth investigations are needed in this particular field so that preventive measures can be taken to control the health related problems of the miners.

\section{ACKNOWLEDGEMENTS}

The authors are highly thankful to the DST PURSE SAP-II, New Delhi for providing financial assistance.

\section{REFERENCES}

1. Acharya, C., Sukla, L.B. and Misra, V.N. (2005). Biological elimination of sulphur from high sulphur coal by Aspergillus-like fungi. Fuel, 84: 1597-1600. doi: 10.1016/j.fuel.2005.02.020

2. Adekola, F.A., Baba, A.A. and Buhari, S. (2012). Physico-chemical characterization and speciation of sulphur of Nigerian coal samples. Journal of Minerals and Materials Characterization and Engineering, 11:965-969. doi: 10.4236/jmmce.2012.1110096

3. Ali, A., Sloane, D.R. and Strezov, V. (2018). Assessment of Impacts of Coal Mining in the Region of Sydney, Australia on the Aquatic Environment Using Macroinvertebrates and Chlorophyll as Indicators. Int. J. Environ. Res. Public Health, 15, 1556-1571; doi: 
10.3390/ijerph15071556.

4. Ali, A.E., Strezov, V., Davies, P. and Wright, I. (2018). River sediment quality assessment using sediment quality indices for the Sydney basin, Australia affected by coal and coal seam gas mining. Sci. Total Environ., 616:695-702. doi: 10.1016/ j.scitotenv.2017.10.259.

5. Ali, AE., Strezov, V., Davies, P. and Wright, I. (2017). Environmental impact of coal mining and coal seam gas production on surface water quality in the Sydney basin, Australia. Environ. Monit. Assess., 189:408-423. doi:10.1007/s10661-017-6110-4

6. Allinson, G., Zhang, P., Bui, A., Allinson, M., Rose, G., Marshall, S. and Pettigrove, V. (2015). Pesticide and trace metal occurrence and aquatic benchmark exceedances in surface waters and sediments of urban wetlands and retention ponds in Melbourne, Australia. Environ. Sci. Pollut. Res., 22:1021410226. doi: 10.1007/s11356-015-4206-3.

7. Alvarez, M.B., Domini, C.E., Garrido, M., Lista, A.G. and Fernández-Band, B.S. (2011). Single-step chemical extraction procedures and chemometrics for assessment of heavy metal behavior in sediment samples from the Bahía Blanca estuary, Argentina. J. Soils Sediments. 11: 657-666. doi: 10.1007/s11368011-0350-7.

8. Aseefa, Y., Mc Culley, H., Murray, M. and Royales, S. (2013). Beyond the numbers. U.S. Bureau of Labor Statistics 2(3): 1-7.

9. Badman, D.G. and Jaffé, E.R. (1996). Blood and air pollution; state of knowledge and research needs. Otolaryngology-head and Neck Surgery. 114: 205208. https://doi.org/10.1016/S0194-59989670166-3

10.Balachandran, M. (2013). Bio-demineralization of Indian bituminous coal by Aspergillus niger and characterization of products. Res J Biotechnol., 8:49-54.

11.Balachandran, M. and Elcey, C.D. (2010). Demineralization of coal by stepwise leaching: A study of subbituminous Indian coal by FTIR and SEM. J. Univ. Chem. Technol. Metallurgy, 45:385-390.

12.Barooah, P. and Baruah, M.K. (1996). Sulphur in Assam coal. Fuel Processing Technology. 46:83 -97. https://doi.org/10.1016/0378-3820(95)00058-5.

13.Barretti, T.W. and Benedict, H.W. (1970). Sulphur dioxide in recognition of air pollution injury to vegetation: A pictorial atlas. Air Pollution Control Association, Pittsburg, pp. 1-17.

14.Brook, C. (2014). Hazelwood coal mine fire February -March 2014: assessment of the short term health impacts in Morwell and the Latrobe Valley. Interim Report, Government of Victoria Department of Health, Melbourne.

15.Cabral, J.P.S. (2010). Can we use indoor fungi as bioindicators of indoor air quality? Historical perspectives and open questions: Sci Total Environ., 408: 4285-4295. doi: 10.1016/j.scitotenv.2010.07.005. Epub 2010 Jul 23.

16.Cao, Q., Jia, B. and Chen, H. (2013). Multi-level control technology of coal mine accident risk. Disaster Adv., 6: 37-44.

17.Catcheside, D.E.A. and Mallett, K.J. (1991). Solubilization of Australian lignites by fungi and other microorganisms. Energy Fuel, 5:141-145. https:// doi.org/10.1021/ef00025a025

18.Chikkatur, A., Sagar, A. and Sankar, T.L. (2009). Sustainable development of the Indian coal sector. Energy, 34: 942-953. doi:10.1016/j.energy.20

\subsubsection{4.}

19.Cohen, M.S. and Gabriele, P.D. (1982). Degradation of coal by the fungi Polyporus versicolor and Poria monticola. Appl. Environ. Microbiol., 44:23-27. doi: 0099-2240/82/070023-05\$02.00/0

20.Cohen, R.A., Petsonk, E.L., Rose C, et al. (2016). pathology in u.s. coal workers with rapidly progressive pneumoconiosis implicates silica and silicates . Am J Resp Crit Care Med., 193:673-680. doi: 10.1164/rccm.201505-1014OC

21.Cornell, K. (2016). Climate change and infectious disease patterns in the United States: Public health preparation and ecological restoration as a matter of justice. http://hdl.handle.net/11603/3006

22.Crawford, D.L. (1993). Microbial transformations of low ranks coal. CRC Press, Boca Raton, pp 223.

23.Drenda, J. (2012). Ocena klimatycznych warunków pracy górników w polskich kopalniach węgla kamiennego i rudy miedzi. (Evaluation of the climatic conditions of miners working in the Polish coal and copper ore mines): Górnictwo i Geologia., 7:19-35.

24.Dutkiewicz, J. (1997). Bacteria and fungi in organic dust as potential health hazard. Ann Agric Environ Med., 4:11-16.

25.Engle, M., Olea, R., 'Keefe, J.O., Hower, J. and Geboy, N. (2013). Direct estimation of diffuse gaseous emissions from coal fires: current methods and future directions. Int. J. Coal Geol., 112: 164 172, doi:10.1016/j.coal.2012.10.005.

26.Faison, B.D. (1991). Microbial conversions of low rank coal. Biotechnol. J., 9:951-956. https:// doi.org/10.1038/nbt1091-951

27.Fakoussa, R.M. (1981). Coal as a substrate for microorganisms: investigation of the microbial decomposition of (untreated) bituminous coals. Doctoral Thesis, Rhein Friedrich-Wilhelms University, Bonn.

28.Fakoussa, R.M. (1992). Mikroorganismen erschließen Kohle-Ressourcen. Bioengineering, 4:21-28.

29.Fakoussa, R.M. and Frost, P.J. (1999). In vivo decolourization of coal-derived humic acids by laccaseexcreting fungus Trametes versicolor. Appl Microbiol Biotechnol., 52: 60-65. doi:10.1007/s002530051487

30.Fakoussa, R.M. and Hofrichter, M. (1999). Biotechnology and microbiology of coal degradation. Appl Microbiol Biotechnol., 52:25-40. doi: 10.1007/ s002530051483

31.FCMHSA Federal Coal Mine Health and Safety Act of 1969 Public Law 91-173, 30 U.S.C. ch. 22, 801 et seq. 1969.

32.Fischer, F. and Fuchs, W. (1927). Uber das Wachstum von Schimmelpilzen auf Kohle. Brennstoff -Chemie, 8:231-233.

33.Frisvad, J.C., Lund, F., Samson, R.A., Hoekstram, E.S. and Filtenborg, O. (2004). Introduction to Food and Airborne Fungi. ASM Press, 7th edition, Netherlands, 283-297. $389 \mathrm{pp}$.

34.Galle, E. (1910). Centralb.f.Bakteriol., Abt.,11:46173.

35.Gamboa, P.M., Jáuregui, I., Urrutia, I., Antépara, I., González, G. and Múgica. (1996). Occupational asthma in a coal miner. Thorax, 51: 867-868. doi:10.1136/thx.51.8.867.

36.Ghose, M.K. (2001). Management of topsoil for geoenvironmental reclamation of coal mining areas. Environ Geol., 40:1405-1410. doi:10.1007/ s002540100321

37.Giam, X., Olden, J.D. and Daniel, S. (2018). Impact 
of coal mining on stream biodiversity in the US and its regulatory implications. Nat. Sustain., 1: 176 doi: 10.1038/s41893-018-0048-6

38.Goswami, S. (2015). Impact of Coal Mining on Environment. European Researcher, 92:185-196. doi: 10.13187/er.2015.92.185.

39.Gotz, G.K.E. and Fakoussa, R.M. (1999). Fungal biosolubilization of Rhenish brown coal monitored by Curie point pyrolysis/gas chromatography/mass spectrometry using tetraethyl ammonium hydroxide. Appl Microbiol Biotechnol., 52:41-48. https:// doi.org/10.1007/s002530051484

40. Hofrichter, M., Bublitz, F. and Fritsche, W. (1997). Fungal attack on coal: I. Modification of hard coal by fungi. Fuel Process. Technol., 52:43-53. https:// doi.org/10.1016/S0378-3820(97)00014-3

41.Holker, U., Schmiers, H., Grosse, S., Winkelhfer, M., Polsakiewicz, M. Ludwig, S., Dohse J and Höfer M. (2002). Solubilization of low-rank coal by Trichoderma atroviride: : evidence for the involvement of hydrolytic and oxidative enzymes by using 14C-labelled lignite. J. Ind. Microbiol. Biotechnol., 28: 207-212. doi:10.1038/sj/jim/7000232

42.Igbinigie, E.E., Aktins, S., van Breugel, Y., van Dyke S., Davies-Coleman, M.T. and Rose, P.D. (2008). Fungal biodegradation of hard coal by a newly reported isolate, Neosartorya fischeri. Biotechnol. J., 3:1407-1416. doi:10.1002/biot.200800227

43.Jelic, T.M., Estalilla, O.C., Sawyer-Kaplan, P.R., Plata, M.J., Powers, J.T., Emmett, M. and Kuenstner, J.T. (2017). Coal mine dust desquamative chronic interstitial pneumonia: a precursor of dust-related diffuse fibrosis and of emphysema . Int J Occup Environ Med., 8: 153 -165. doi: 10.15171/ ijoem.2017.1066.

44.Jiang, L., Lin, M., Zhang, Y., Li, Y.P., Xu, X. and Li, S. (2013). Identification and characterization of a novel trehalose synthase gene derived from salinealkali soil metagenomes. PLoS One, 8:1-11. doi: 10.1371/journal.pone.0077437.

45. Johnstone, K.M., Rainbow, P.S., Clark, P.F., Smith, B.D. and Morritt, D. (2016). Trace metal bioavailabilities in the Thames estuary: Continuing decline in the 21st century. J. Mar. Biol. Assoc. UK., 96:205-216. doi: 10.1017/S0025315415001952.

46.Kar, D. and Palit, D. (2017). Study of physicochemical characteristics of overburden dump soil in selected coal mining areas of Raniganj coal fields, West Bengal, India. International Research Journal of Natural and Applied Sciences, 4:1-12.

47.Kelsall, J.E., Samet, J.M., Zeger, S.L. and Xu, J. (1997). Air pollution and mortality in Philadelphia, 1974-1988. Am J Epidemiol., 146:750-762. doi:10.1093/oxfordjournals.aje.a009351

48.Laborda, F., Fernandez, M., Luna, N. and Monistral, I.F. (1997). Study of the mechanisms by which microorganisms solubilize and/or liquefy Spanish coals. Fuel Process. Technol., 52:95-107. doi: 10.1016/ S0378-3820(97)00019-2

49.Lieske, R. and Hofmann, E. (1928). Untersuchungen fiber die Mikrobiologie der Kohlen und ihrer naturlichen Lagerstatten. I. Mitteilung: Die Mikroflora der Braunkohlengruben. Brennstoff-Chemie, 9:174-178.

50.Lipman CB (1937) Bacteria in coal. J Bacteriol., 34: 483-488 PubMed PMID: 16560072; PubMed Central PMCID: PMC545253.

51.Lovesan, V.J., Kumar, N. and Singh, T.N.
(1998). Effect of the bulk density on the growth and biomass of the selected grasses over overburden dumps around coal mining areas, Proceedings of the 7th National Symposium on Environment, Dhanbad, Jharkhand, India. pp., 182--185.

52.Ma, J. and Dai, H. (2017). A methodology to construct warning index system for coal mine safety based on collaborative management. Saf. Sci., 93:86 -95. doi: 10.1016/j.ssci.2016.11.012.

53.Machnikowska, H., Pawelec, K. and Podgorska, A. (2002). Microbial degradation of low rank coals. Fuel Process. Technol., 77:17-23. https://doi.org/10.1016/ S0378-3820(02)00064-4

54.Maharana, J.K. and Patel, A.K. (2013). Physicochemical characterization and mine soil genesis in age series coal mine overburden spoil in chronosequence in a dry tropical environment. J Phylogen Evolution Biol. 1: 101-107 doi: 10.4172/23299002.1000101

55.Makdoh, K. and Kayang, H. (2015). Soil physicochemical properties in coal mining areas of Khliehriat, East Jaintia Hills District, Meghalaya, India. Int. Res. J. Environ. Sci., 4:69-76.

56.Mishra, V.K. and Shukla, R. (2016). Aquatic macrophytes for the removal of heavy metals from coal mining effluent. In: Ansari A.A., Gill A.A., Lanza R., Newman G., editors. Phytoremediation: Management of Environmental Contaminants. Volume 3. Springer International Publishing; Cham, Switzerland pp. 143156.

57.Monistral, I.F. and Laborda, F. (1994). Liquefaction and or solubilization of Spanish coals by newly isolated microorganisms. Fuel Process. Technol., 40:205216. https://doi.org/10.1016/0378-3820(94)90143-0

58.Nie, B., Huang, X., Xue, F., Chen, J., Liu, X., Meng, Y. and Huang, J. (2018). A comparative study of vocational education and occupational safety and health training in China and the UK. Int. J. Occup. Saf. Ergon., 24, 268-277. https:// doi.org/10.1080/10803548.2016.1270042

59.Nigam, G.K., Sahu, R.K., Jitendra, S. and Sonwanshi, R.N. (2015). A study on physicochemical characteristics of open cast mine water. $J$ Ind Pollut Contr., 31: 119-127.

60.Nyakuma, B.B. (2015). Physicochemical characterization of low rank Nigerian coals arXiv preprint arXiv: 1506.02068.

61.Obtułowicz, K. (2006). Environment and its impact on allergy. Problemy Higieny i Epidemiologii., 87: 359363.

62.Osipowicz, B., Jablonski, L., Siewinski, A. and Rymkiewicz, A. (1994). Biodegradation of hard coal and its organic extract by selected microorganisms. Fuel, 73:1858-1862.

63.Pagenkopf, G.K. (1983). Gill surface interaction model for trace-metal toxicity to fishes: Role of complexation, $\mathrm{pH}$, and water hardness. Environ. Sci. Technol., 17:342-347. doi: 10.1021/es00112a007.

64.Perret, J.L., Plush, B., Lachapelle, P., Hinks, T.S.C., Walter, C., Clarke, P., Irving, L., Brady, P., Dharmage, S.C. and Stewart, A. (2017). Coal mine dust lung disease in the modern era. Respirology, 22:662670. doi: 10.1111/resp.13034.

65.Piontek, M. and Bednar, K. (2010). Biodeteriogenne grzyby w kopalniach węgla kamiennego (Biodeteriogenic molds in coal mines): Zeszyty Naukowe Uniwersytetu Zielonogórskiego, Inżynieria 
Środowiska. v. 18, p. 57-63.

66.Plakolli, F., Beqiri, L.P. and Millaku, A. (2010). The microflora and physico-chemical properties of lignite from the Mirash mine, near Kastriot. Mater. Sci. Technol., 44:271-275.

67.Pollock, D.E., Potts, J.D. and Joy, G.J. (2010). Investigation into dust exposures and mining practices in mines in the southern Appalachian region. Min Eng., 62:44-49.

68.Polman, J.K., Stoner, D.L. and Delezene-Briggs, K.M. (1994). Bioconversion of coal, lignin and dimethoxybenzyl alcohol by Penicillium citrinum. J Ind Microbiol Biotechnol., 13:292-299. https:// doi.org/10.1007/BF01569731

69.Potter, M.C. (1908). Bacteria as agents in the oxidation of amorphous carbon. Proceedings of the Royal Society of London. Series B, containing papers of a biological character, 80:239-259. https:// doi.org/10.1098/rspb.1908.0023

70.Prasanth, A., Nila, A., Bhuvaneswari, S.N. and Udaya Prakash, N.K. (2011). An investigation on airborne mycoflora near lignite mine in Tamil Nadu, India. Int J Appl Biol Pharm., 2:35-39.

71.Quigley, D.R., Wey, J.E., Breckenridge, C.R. and Stoner, D.L. (1988). The influence of $\mathrm{pH}$ on biological solubilization of oxidized low-rank coal. Resour Conserv Recycl., 1:163-174.

72.Rai, A.K., Paul, B. and Singh, G. (2011). A study on physico chemical properties of overburden dump materials from selected coal mining areas of Jharia coalfields, Jharkhand, India. International Journal of Environmental Sciences, 1:1350-1360.

73.Rajak, K.K., Yadav, B.K., Mandal, R.B.., Saxena, V.K. and Mandre, N.R. (2014). Bio-desulphurization of Makum (Assam) coal. Proceedings of the XI International Seminar on Mineral Processing Technology. pp. 976-980.

74.Ralte, V. (2017). Effect of coal mining on soil physico -chemical properties of Nokrek Biosphere Reserve of Meghalaya, northeastern India. Science Vision, 17: 228-237. 10.33493/scivis.17.04.07.

75.Rdzanek, M., Pusz, W., Gębarowska, E., and Pląskowska, E. (2015). Airborne bacteria and fungi in a coal mine in Poland. J Cave Karst Stud., 77:177182. doi: $10.4311 / 2015 \mathrm{MB} 0102$

76.Schroeder, H. (1914). The bacterial content of coal. Zentralblatt für Bakteriologie, 41: 460-469.

77.Selvi, V.A., Banerjee, R., Ram, L.C. and Singh, G. (2009). Biodepolymerization of low rank Indian coal. World J Microbiol Biotechnol., 25:713-720.

78.Sharma, A. (2016). Studies on the fungal flora of two coal mines of Jammu province. M.Phil Dissertation, University of Jammu, India.

79.Sharma, A. and Sumbali, G. (2017). Prevalence of fungal flora in the acidic environment of anthracite and lignite coal mines of Jammu. Bulletin of Environment, Pharmacology and Life Sciences, 6:86-93.

80.Silva, L., Oliveira, M., Phillipi, V., Serra, C., Dai, S., Xue, W., Chen, W., O'Keefe J, Romanek, C., Hopps, S. and Hower, J. (2012). Geochemistry of carbon nanotube assemblages in coal fire soot, Ruth Mullins fire, Perry County, Kentucky. Int. J. Coal Geol., 94: 206-213, 10.1016/j.coal.2011.04.003.
81.Silva-Stenico, M.E., Vengadajellum, C.J., Janjua, H.A., Harrison, S.T.L., Burton, S.G. and Cowan, D.A. (2007). Degradation of low rank coal by Trichoderma atroviride ES11. J Ind Microbiol Biotechnol., 34:625631. doi: 10.1007/s10295-007-0223-7

82.Stewart, D.L., Thomas, B.L., Bean, R.M. and Fredrickson, J.K. (1990). Colonization and degradation of oxidized bituminous and lignite coals by fungi. J. Indust. Microbiol., 6:53-59.

83.Tao, X.X., Chen, H., Shi, K.Y. and Lv, Z.P. (2010). Identification and biological characteristics of a newly isolated fungus Hypocrea lixii and its role in lignite bioconversion. Afr. J. Microbiol. Res., 4:1842-1847.

84.Taylor, T.N., Taylor, E.L. and Krings, M. (2009). Paleobotany: The biology and evolution of fossil plants. Amsterdam; Boston: Academic Press, ISBN 978-0-12-373972-8.

85.Tian, R. (2012). Practices and considerations on management of coal mine occupational safety and health. Coal Eng., 10: 132-134.

86.Tripathi, R.C., Jain, V.K. and Tripathi, P.S.M. (2009). Fungal biosolubilization of Neyveli lignite into humic acid. Energ Source., 32:72-82. https:// doi.org/10.1080/15567030802464354

87.Tulsiyan, R.K., Sinha, N.K. and Kumar, V. (2017) Isolation and identification of fungi from coal mines near Hazaribagh and their diversity study . J Cell Sci Apo., 1: 102-103.

88.US Energy Information Administration (2017). Coal Explained. Energy Explained. https://www.eia.gov/ energyexplained/index.php?page=coal_home

89.Volland, S., Bayer, E., Baumgartner, V., Andosch, A., Lütz, C., Sima, E. and Lütz-Meindl, U. (2014). Rescue of heavy metal effects on cell physiology of the algal model system micrasterias by divalent ions. J. Plant Physiol., 171:154-163. doi: 10.1016/ j.jplph.2013.10.002.

90. Wang, J.Z., Peng, S.C., Chen, T.H. and Zhang, L. (2016). Occurrence, source identification and ecological risk evaluation of metal elements in surface sediment: Toward a comprehensive understanding of heavy metal pollution in Chaohu Lake, Eastern China. Environ. Sci. Pollut. Res., 23:307-314. doi: 10.1007/s11356-015-5246-4.

91.Winner, W.E., Mooney, H.A. and Robert, A, (1985). Goldstein Sulfur dioxide and vegetation: Physiology, ecology, and policy issues. Stanford University Press.

92.Yoltas, A., Gunyar, O.A., Uztan, A.H., Ates, M. and Boyacioglu, H. (2015). Determination and statistical analyses of the total microfungal flora of a coal mine in Manisa. J. Appl. Biol. Sci., 9: 73-81.

93.Yuan, H., Yang, J. and Chen, W. (2006). Production of alkaline materials, surfactants and enzymes by Penicillium decumbens strain P6 in association with lignite degradation/solubilization. Fuel, 85:1378-1382 doi10.1016/j.fuel.2005.12.003

94.Zhou, L., Cao, Q., Yu, K., Wang, L. and Wang, H. (2018). Research on Occupational Safety, Health Management and Risk Control Technology in Coal Mines. Int J Environ Res Public Health, 15(5): 868 doi: [10.3390/ijerph15050868] 